\title{
STUDYING THE MUNICIPAL SOLID WASTE MANAGEMENT SYSTEM IN MEERUT CITY, UTTAR PRADESH
}

\author{
Usha Rani ${ }^{1}$ and B. W. Pandey ${ }^{2}$ \\ ${ }^{1}$ Research Scholar, ${ }^{2}$ Associate Professor, \\ Department of Geography, Delhi School of Economics, University of Delhi, Delhi, India \\ Email: ushar489@gmail.com, bwpdsegeo@gmail.com
}

\begin{abstract}
Solid waste is the unwanted and discarded solid materials generated from different places such as household, residential, industrial and commercial; activities in a given area. Meerut is the second largest city in the National Capital Region (NCR) after Delhi. Meerut Municipal Corporation (MMC) also known as Meerut Nagar Nigam (MNN) is sole agency for collection, transportation and disposal of solid waste management. The purpose of the paper is to analyse the status of municipal solid waste in Meerut city. Data was collected from different organisations and through primary survey. Out of total municipal wards, 250 respondents from different income groups (HIG, MIG \& LIG) have taken into account in order to know the ground realities and their perception. Observation method and discussion was conducted with the MNN officials. The total amount of waste generation is directly related to the density of population, economic status and land use pattern of the particular area. There is positive correlation between waste generation and socio-economic development. Per capita of municipal solid was $0.46 \mathrm{~kg}$ per capita/per day in 2006 which touched the figure of $0.53 \mathrm{~kg}$ per capita/per day. All the high population density wards have high rate of waste production and low density of population zones, corresponding with low quantity of waste generated. The street sweepings and collection of garbage from the receptacles are carried out by the sanitary workers of civic agencies in Meerut. In this stage, collection is not very efficient even though large numbers of private sweepers are engaged in waste collection from door to door at a nominal charge, particularly in big apartments and group housing societies.
\end{abstract}

Key word: Solid Waste, Generation, Collection, Dustbins, Disposal, Meerut

\section{Introduction}

Land resources are the most important features of environment which is utilized for the satisfaction of human wants (Pandey, 2014). Urban environmental sustainability assessment is increasingly a part of urban planning, from the perspective of mitigating local and global impacts. Today, 54 per cent of the world's population lives in urban areas, which is expected to increase to 60 per cent by the year 2030. The urbanization has several negative impacts on environment in which urban solid waste management is considered as one of the most serious and challenging issues confronting municipal authorities in developing countries (Bhat and B., 2018). Waste is an unavoidable by product of most human activities. (Anand, 2010).Nowadays, solid waste management is a problem of major relevance for all local and national authorities. Solid waste management fall under the sustainable development goals 6 and 7 about the clean water and sanitation and affordable and clean energy. In urban area, there are several problems such as lack of adequate housing facilities, large scale unplanned haphazard urban sprawl and illegal encroachments, increasing no of vehicles leading to vehicle congestion and crowding, Lack of access to treated water supply and depletion of water level, Inadequate health and sanitation facilities, limited land space and increasing pressure on ecological services, lack of comprehensive solid waste management systems. Many cities face the problem of uncollected municipal solid waste littered. Tourists are many problems including solid waste management in Dharamsala town. Wastes generated from different activities concentrate human health hazards and have negative implication on the man and environment (Anand and Singh, 2012). Markandey (2016) prepared a report of the work which has been done during the 2012- 2016 on urban geography, including the waste disposal. She found that researches in India connect the issues at global problems in urban areas. Saxena and Khan (2016) have found that quality of life (QOL) determined by various factors including the waste disposal facilities. They have done a research to find the out spatial pattern of environmental 
degradation and its impact on QOL, taking the case studies of Sriganganagar, Bharatpur, Bikaner, Kota and Tonk cities of Rajasthan. It is found that in all the cities, chosen for study, waste collection and disposal facilities are unsatisfactory. Improper disposal of municipal solid waste creating unsanitary conditions, and these conditions in turn can lead to environmental pollution and to outbreaks of vector-borne disease, spread by rodents and insects. Managing the solid waste is one of the necessary services provided by civic agencies in the country to keep urban areas clean. In India, cities and towns generate on an average 300 - 500 grams of solid waste per capita per day, which is approximately 80,000 metric tonnes per day. About $3 / 4$ of the MSW generated in urban India is collected and disposed off in nonscientifically non - proper managed dumping grounds. Spreading the waste is leading to insanitary living conditions.

\section{Study Area}

The district Meerut lies between $28^{\circ} 54^{\prime}$ and $29^{\circ} 15^{\prime}$ north latitudes and longitude $77^{\circ} 77^{\prime}$ and 78.14' east longitudes. On the north it is surrounded by the district of Muzaffar nagar and on the south by Ghaziabad, in the east by district Bijnor and Jyotiba Phule Nagar, in the west by district Baghpat. As per Census of India 2011, Uttar Pradesh has 199.6 million inhabitants, having 75districts in state and these are grouped into 18 divisions, which includes Aligarh, Azamgarh, Allahabad, Kanpur, Gorakhpur, Chitrakoot Dham, Jhansi, Devi Patan, Faizabad, Bareilly, Basti, Vindhyachal (Mirzapur), Moradabad, Meerut, Lucknow, Varanasi and Saharanpur. It is about 70 kilometres away from Delhi. Meerut is rectangular in shape. Meerut Nagar Nigam covers an area of 142 square kilometres (District Census Handbook Meerut, 2011). According to Census of India, it is having 13,05429 population in 80 municipal wards but at present the number of wards are 90 .

\section{Data Sources and Methodology}

Keeping in mind the aims and objectives of this research study, it is based on primary as well as secondary data sources. The ground trotting of the research cannot be achieved without intermingle the primary data in the investigation. A number of studies have concluded that there is dire need to conduct the research on status of management of solid waste in Meerut city. Present paper is based on primary as well as secondary data sources. Secondary data collected from government, semi-government and private publications from Meerut Statistical Handbook, and Census of India etc. Required data and comprehensive information and published available materials related to municipal solid waste management collected from Meerut Municipal Corporation (MMC), Central Pollution Control Board (CPCB), State Pollution Control Board (SPCB), and others. Data and information taken from Meerut nagar nigam, regional centre for urban \& environmental studies, Lucknow. In order to know the ground realities, field work and primary survey was conducted in study area. Out of eighty municipal wards, nine have been selected on random basis, selecting three from each group (HIG, MIG \& LIG). Total 250 respondents from different municipals wards from different incomes groups have been taken into account. Observation and PRA methods have been used to know the existing situation. Discussion was done with the MMC officials. The processing of collected data was taken up with various tabulation, mapping and graphical representation work like line and bar graphs, flow charts and pie diagrams.

\section{RESULTS AND DISCUSSION}

\section{Generation of Urban Municipal Solid Waste}

Municipal solid waste management includes the steps: collection, segregation, storage, transportation and disposal of the waste materials. The urban population in India generated about $1,14,576$ tonnes per day of municipal solid waste (MSW) in the year 1996, which is predicted to increase four-fold to about 4,40,460 tonnes per day by the year 2026. The composition and generation of solid waste influence by the land use, population size, family size, socio- economic conditions, dietary habits, lifestyle of the people. Floating population also contributes to waste generation in the city as a big percentage of population come for jobs and go back after short period of time; generally, they buy packaged food items. In 2006, the generation amount of municipal solid waste was recorded 554 metric tonnes per day from the area under the Meerut nagar nigam, which has been proposed to be increased to 865 metric tonnes/day in 2019, so, 56 per cent (311 tonnes/day) increased during the 13 years, and further this amount is increasing at fast rate. Per capita of municipal solid was $0.46 \mathrm{~kg}$ per capita/per 
day in 2006 which touched the figure of $0.53 \mathrm{~kg}$ per capita/per day (Fig. 1). As per one estimate, by year 2021, there will be 1150 metric tonnes of solid waste in the city.

There are spatial variations in the quantity of the municipal solid waste generation in the area under MMC but one thing is clear that highest waste quantity comes from highly populated wards. During the field work, it was noticed that amount of waste generation per capita was higher in the high developed areas such Civil Lines, Shastri Nagar, Saket. Segregation of wet waste from dry waste is important and the household practicing segregation depicts the thoughts, behaviours and willingness of family member on importance of waste segregation. Composition of waste includes both degradable and non-degradable, degradable includes the waste from kitchen, garden, restaurant, and non- degradable consist recyclable such as paper, plastic, board, metals, but at present majority of the households in Meerut city give mixed waste to waste collectors. As per JANNURM City Development Plan for Meerut the moisture content of was 45 per cent, which indicates the waste is feasible for composting. People were not using two different bins in their houses for the segregation of waste such as bio-degradable and nonbio- degradable waste category. At household level majority of families use only one dustbin for disposal of waste with minimum segregation. The waste collectors also segregate only recyclable waste from dustbins and dump all the remaining waste at unauthorized spots. There should be enhancement of awareness regarding the segregation process of waste at source (household) level, because low level of awareness causes low participation of people.

\section{Figure 01: Per Capita Generation of Municipal Solid Waste in Meerut City}

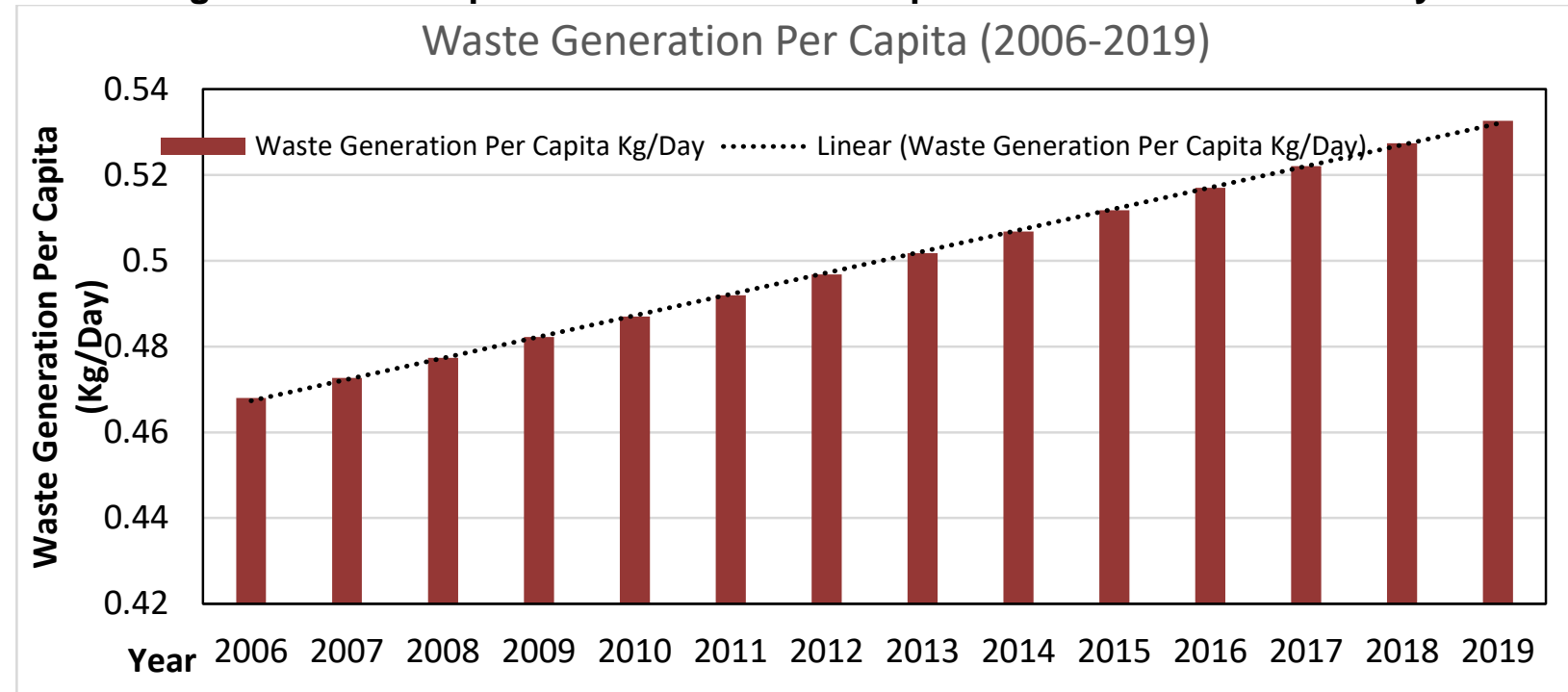

\section{Collection and Transportation of Municipal Solid Waste}

In all the municipal wards of Meerut, waste is being collected by the door to door collection methods through the Tata vehicles. Waste collectors start the work since in morning 9 am to 1 pm. Apart from MMC workers, private sweepers are also working in the area. Even some families give their garbage to private sweepers. It has been observed that highly populated areas have less number of dustbins and dhalos as compared to low population density areas in Meerut. As per MMC officials, people steal and sell the iron made dustbins to the junk dealers in the night time in LIG area. Highly populated areas have narrow street, where door to door collection system through Tata vehicle is being hindered. The people throw their waste outside the house or on road, street, drains or nearby vacant plots. There are found many heaps of solid waste at various places, it was lying on streets, roads creating the hurdles for the people. During the field work, it has been found that people of Low Income Group (LIG) areas have more grievances for the collection and disposal of solid waste as compared to High Income Group areas. The difference between HIG and LIG is clearly observed in terms of availability of waste infrastructure and management in the Meerut city. 31 and 33 per cent respondents told that there is Trice a day and Daily waste collection from dustbins by the MMC respectively. Most residents drop the waste outside their residence, which in-turn is swept away by street sweeping and lifted by means of handcart rickshaw trolley by Nagar Nigam workers to the nearby opens dumps. 85 per cent respondents also argued that there is prevailing of unhygienic insanitary conditions in the study area. 


\section{Solid Waste Disposal System}

After the collection of waste next process is disposal of the solid waste. Proper waste collection and disposal is a great challenge for the concerned civic agencies in the Meerut city. Due to poor collection and inadequate transportation the accumulation of MSW is a major problem in highly populated areas of city. Management of municipal solid waste is critical due to unavailability of treatment and disposal facilities for MSW which is generated regularly in metropolitan cities. Landfill methods have been practiced since ancient period but landfill liner will leak, allowing hazardous waste to percolate and contaminate the groundwater (Bhat and B., 2018). The unscientific waste disposal has adverse effects on all components of environment i.e. air, water, soil and land etc. and even to human health. The waste of city is increasing but land for disposal is decreasing, therefore, the problem of management of municipal solid waste will be acute in coming future. About $3 / 4$ respondents reported that now waste disposal has become a critical problem in the Meerut city (Fig. 2).

Figure 02: Respondent's view of on Criticality of Waste Problem

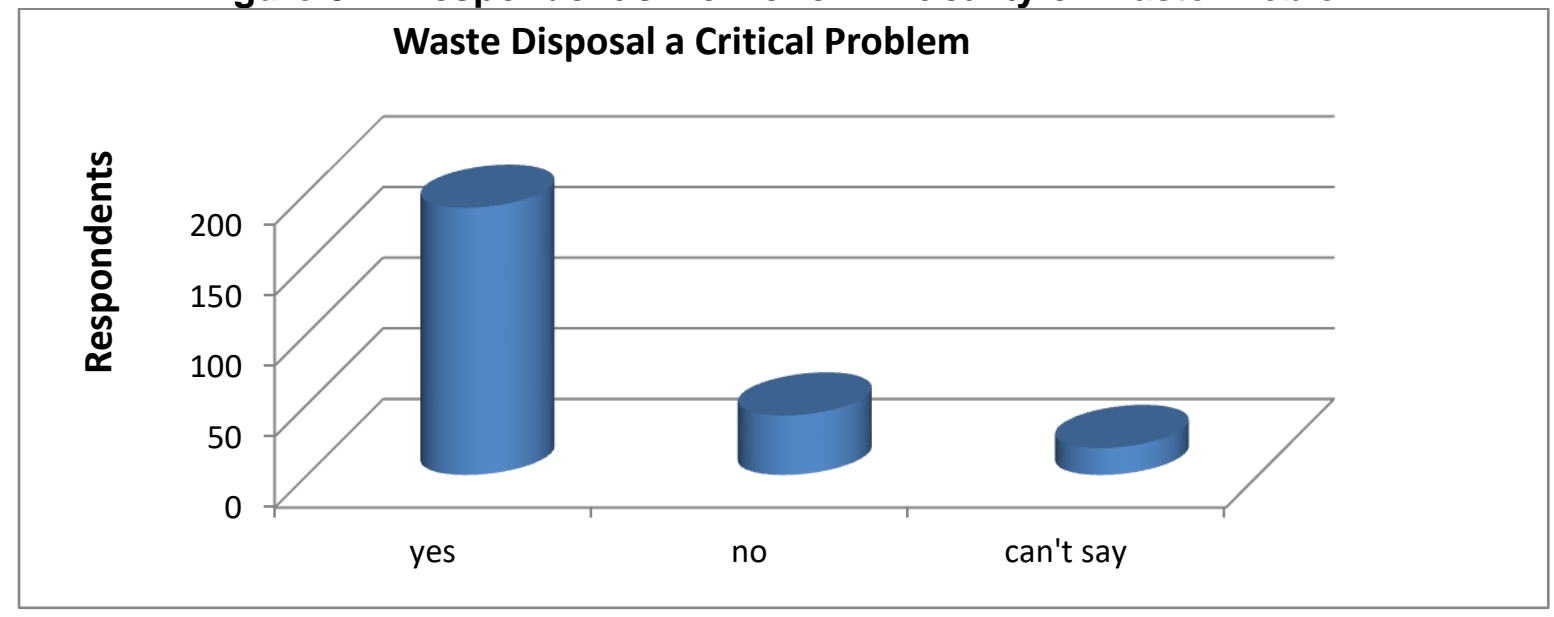

The entire waste is dumped in out skirts of city. The solid waste is dumped in landfills without sorting or treatment leading to air, land and water pollution/foul odour. The collected municipal waste from the city is landfilled at Lohia Nagar Hapur road, near Gaushi Pur village and Gawdi. These sites pose unhygienic condition to local people. In future, proposed land for disposal of waste can be finding out in other directions in the Meerut district. One MNC official told that it is matter of great concern that Meerut city generate huge amount of municipal waste and but so far we have not installed any composting plant whereas like a Municipality in Ghaziabad installed a composting plant while it generate only 250 tonnes of waste.

\section{Availability of Infrastructure for SWM}

In urban local bodies (ULBs) solid waste management sector occupies primary focus but suffers from lack of adequate community involvement and constraints with required funding and respect to safe disposal. The drains of Meerut city play very significant role as bigger sink of solid waste. There is different waste infrastructure which is engaged for the management of municipal solid waste. Under the area of MMC, total 315 drains are there. In order to clean the drains, porklane/fassi machines uses for the big drains while small drains cleaned by JCB. Presently, 9 JCB are working for the cleaning the drains. There are 24 big drains, having the 45.9 kilometres length which are generally cleaned by JCB, Big porklane and fassi machines while 195 drains with 142 kilometres distance are cleaned by the small porklane and remaining are 53 of about 51 kilometres long which are cleaned by sanitary workers of Nagar Nigam (MMC, 2018). Out of total 314 machines which includes JCB, loader, R.C., D.P., Truck, Tractor trolley, Tata ACE, porklane, fassi etc. for using the garbage cleaning. 136 are in Suraj Kund depot, 121 in Delhi vehicle depot and remaining are Kankar Khera depot (Table 1). There are 160 Tata vehicles which are being used for the collection of garbage from door to door in all the municipal wards of Meerut Nagar Nigam.

As per the information received from the MMC, There are two categories of safaikaramcharis (SKs) permanent and outsourcing, 945 are permanent safaikaramcharis and approximately 50 per cent are working in 33 municipal wards while only 101 SKs are working in Kanker Khera zone, all the safaikaramcharis mark their attendance through the 
biometric. It is realized that there is pressing need of requirement of recruitment of more number of staff and vehicles in collection, transportation, disposal, treatment process.

Table 01: Availability of Resources for Sanitation Management in Meerut city

\begin{tabular}{|l|l|c|c|c|c|}
\hline$\#$ & \multicolumn{1}{|c|}{ Vehicles Names } & $\begin{array}{c}\text { Suraj Kund } \\
\text { Vehicle Depot }\end{array}$ & $\begin{array}{c}\text { Delhi Road } \\
\text { Vechicle Depot }\end{array}$ & $\begin{array}{c}\text { Kankar Khera } \\
\text { Vehicle Depot }\end{array}$ & Total \\
\hline 1. & JCB & 4 & 3 & 2 & 9 \\
\hline 2. & Loader & 3 & - & 1 & 4 \\
\hline 3. & R.C. & 2 & 2 & 1 & 5 \\
\hline 4. & D.P. & 4 & 4 & 3 & 11 \\
\hline 5. & Truck & 15 & 10 & 4 & 29 \\
\hline 6. & Tractor Trolley & 28 & 22 & 10 & 60 \\
\hline 7. & Tata ACE & 66 & 66 & 28 & 160 \\
\hline 8. & Robot & 3 & 3 & 2 & 8 \\
\hline 9. & Large Pork lane & 3 & 3 & 1 & 7 \\
\hline 10. & Small Porklane (jeep) & 00 & 1 & 1 & 2 \\
\hline 11. & Small Porklane (Chain) & 5 & 5 & 4 & 14 \\
\hline 12. & Dozer & 1 & 1 & 0 & 2 \\
\hline 13. & Fassi Machine & - & 1 & - & 1 \\
\hline 14. & Fassi Machine (Small) & 1 & - & - & 1 \\
\hline 15. & Sweeping & 1 & - & - & 1 \\
\hline & Total & 136 & 121 & 57 & 314 \\
\hline
\end{tabular}

Source: Meerut Municipal Corporation, 2018

\section{Conclusion}

During the primary data collection it was also observed that the socio- economic conditions play an important role in waste composition and generation. Mixed waste is reaching at landfill sites as the residents throw garbage improperly without segregation and even all the houses are not in the services for door to door collection in the study area. The present infrastructure for collection, storage and transportation of waste is not as per requirement of the people; it needs repairs, enhancement in capacity and up gradation. Spreading the waste is leading to insanitary living conditions. At present, there are found many hotspots, mainly in low income area where proper collection and disposal of waste is needed. Having analysed, it is now realized that there is urgent need to have a healthy and resource-efficient society in which wastes are prevented, re-used, reduced and recycled wherever feasible and beneficial, and disposed-off safe. In order to overcome the problems in solid waste management sector, segregation, composting and waste to energy project should be promoted. For this purpose, Out of the collection and disposal funds, MMC should allocate special fund 5-10 per cent. Side by side public awareness and community participation through social media needs to be encouraged. For achieving healthy, hygienic and liveable environment and sustainability in the Meerut city, municipal waste processing should be technically sound, financially viable, eco-friendly.

\section{Acknowledgements}

Both the authors are thankful to the Professor R.B. Singh, Secretary General and Treasurer of International Geographical Union (IGU) and the Department of Geography, University of Delhi and University Grants Commission for valuable suggestions and guidance and funding for the pursuing the research on solid waste management.

\section{References}

1. Anand, S. and Singh, A. (2012) Tourism and Solid Waste Management In Singh, R. B. and Hietala, Reija (eds.) Livelihood Security in Northern western Himalaya, Springer, Japan, pp 189-202.

2. Anand, Subhash (2010) Solid Waste Management in Delhi, Mittal Publication, New Delhi.

3. Anand, Subhash (2014) Emissions From Landfill Sites and Solid Waste Management: An Approach to Mitigate Urban Climate Change in Delhi, India, The Horizon: Journal of Social Sciences, No. 1, Volume, V, pp. 100-105.

4. Bhat, Komala and B. Anil. (2018) Site Suitability Analysis for Solid Waste Disposal By Using Remote Sensing and GIS Techniques : A Case Study of Sirsi Town, Uttarakannada District, 
The Deccan Geographer, Vol. 56, No. 1\&2, June and December, pp. 47-54

5. Darshini, Mahadevia, et al. (2008) Solid Waste Management in Indian Cities (Status and Emerging Practice). Concept Publishing Company, New Delhi, p. 45.

6. http://www.censusindia.gov.in/2011census/population_enumeration.html

7. http://www.meerutnagrnigam.in

8. http://www.rcueslucknow.org/publication/NewsLetter

9. Jain, A. and Singhal, M. K. (2014) Waste Minimization in Mishra, G.C. (Ed) Environmental Sustainability: Concepts, Principles, Evidences and Innovations, Excellent Publishing House, New Delhi, pp. 11-18.

10. Jain, M.C. (2004) Urban Waste Environmental Threat and a Source of Energy, NISTADS News, vol. 6 No.1.

11. JANNURM (2006) Consultancy Services for Preparation of the City Development Plan (CDP) for Meerut in the State of Uttar Pradesh under JNNURM, City Development Plan Final Report, Meerut.

12. Markandey and Kalpana (2016) Urban Geography In: R. B. Singh (Ed) Progress in Indian Geography, Indian National Science Academy, New Delhi, pp. 105-121.

13. Pandey, B.W. (2014) Land use change, Sustainability, Planning and Technology for Land Resource Management, In Pandey, B.W. (Ed.) Dynamics of Land Use Change; Sustainability and Management, Research India Press, New Delhi, pp.1-15.

14. Raisinghani, H. (2015) Solid Waste Management Planning Using GIS: A Case Study for Aurangabad, India, Geosphere, An International Journal of Geography, Vol. 2 Issue 2, October 2015, pp. 82-90.

15. Raman, E. Kumar, P. and Anand. S. (2019) Health Hazards of Bhalaswa Landfill Site in Delhi, Indian Journal of Geography, Vol. XXII, January, pp.27-40.

16. Regional Centre for Urban and Environmental Studies (RCUES) (2008) Detailed Project Report for Solid Waste Management in Meerut, Uttar Pradesh, Lucknow.

17. Saxena, H.M. and Khan, M.Z.A. (2016) Urbanization, Environmental Degradation \& Quality of life, Rawat Publications, New Delhi.

18. Singh, R.B. and Anand, Subhash (2008) Current Status of Municipal Solid Waste Management Practices in Delhi", NAGI, Annals, Vol. XXVIII, No. 1, p-36-49.

19. Vij, Dimpal and Aggarwal, Babita (2012) Domestic Solid Waste Management: A Case Study of Ghaziabad District of UP., In Bhatt, M.S. and Illiyan, Asharaf (Eds.) Solid Waste Management: An Indian Perspective, Synergy Books India, New Delhi, pp 228-238.

20. Yadav, K. Bansal, M.L., Kaushik, S.P. (2014) Managing the Municipal Solid Waste: Comparative Study of Faridabad City with other Cities of India, Annals of the National Association of Geographers, India, Volume XXXIIV, No. 2, pp. 137-145. 